\title{
Kecerdasan Emosi Dan Depresi Pada Mahasiswa Yang Sudah Menikah
}

\author{
Azizah Fitriah \\ Universitas Muhammadiyah Banjarmasin (UMB)
}

\begin{abstract}
Every human being will one day experience a tense period in the short term when facing known problems such as career pressures, family disputes or quarrels, material pressures, and personal despair, and we will think that this is depression, which is not is an important problem because it will resolve itself, but none of these fleeting conditions is depression. Good emotional intelligence can reduce aggression, especially in adolescents. Therefore, if emotions are managed successfully, the individual will be able to entertain themselves when overwritten by sadness, can release anxiety, moodiness or offense and rise quickly again from it all. This research is field research with a correlational approach, exploring the relationship between depression and emotional intelligence in married students. The results of the hypothesis test show that between emotional intelligence and depression in married students has a significant negative relationship ( $X Y=-0.411$; sig $=0.014<0.05)$. This is in accordance with the data obtained from the SPSS 19 for Windows program, stating that $r$ table 0.334 and $r x y$ ( $r$ hit) -0.411 , said to be significant if $r x y=0.411>r$ table $=0.334$. In other words, the higher the emotional intelligence of students who are married, the lower the possibility of depression.
\end{abstract}

Keywords: depression; emotional intelligence; married; college student

\begin{abstract}
Abstrak
Setiap manusia suatu saat akan mengalami masa tegang dalam jangka pendek saat menghadapi masalah-masalah yang telah dikenal seperti tekanan-tekanan karier, sengketa atau pertengkaran keluarga, tekanan-tekanan materi dan keputusasaan-keputusasaan pribadi, dan kita akan menyangka bahwa inilah depresi, yang bukan merupakan sebuah masalah penting karena akan terselesaikan dengan sendirinya, akan tetapi tidak satupun dari kondisi-kondisi yang cepat berlalu ini merupakan depresi. Kecerdasan emosional yang baik dapat mengurangi agresi, khususnya pada remaja. Oleh sebab itu apabila emosi berhasil dikelola maka individu akan mampu menghibur diri ketika ditimpa kesedihan, dapat melepas kecemasan, kemurungan atau ketersinggungan dan bangkit kembali dengan cepat dari itu semua. Penelitian ini adalah penelitian lapangan dengan pendekatan korelasional, menggali hubungan anatara dapresi dengan kecerdasan emosi pada mahasiswa yang telah menikah. Hasil uji hipotesis diperoleh hasil bahwa antara kecerdasan emosi dengan depresi pada mahasiswa yang telah menikah mempunyai hubungan negatif yang signifikan $(r \mathrm{xy}=-0,411 ; \operatorname{sig}=0,014<0,05)$. Hal ini sesuai dengan data yang telah diperoleh dari program SPSS 19 for windows, menyatakan bahwa $\mathrm{r}$ tabel 0,334 dan $\mathrm{r}$ xy ( $\mathrm{r}$ hit) -0,411, dikatakan signifikan apabila $\mathrm{r} x y=0,411>$ $\mathrm{r}$ tabel $=0,334$. Dengan kata lain semakin tinggi kecerdasan emosi mahasiswa yang telah menikah maka semakin rendah kemungkinan mengalami depresi.

Kata Kunci: depresi, kecerdasan emosi;, menikah; mahasiswa
\end{abstract}


Dewasa ini kesehatan mental telah menjadi masalah global dan diperkirakan akan semakin meningkat jumlahnya dari tahun ke tahun. WHO memprediksikan bahwa pada tahun 2020 depresi akan menjadi penyebab penyakit kedua terbanyak di dunia setelah penyakit kardiovaskular. Prevelensi depresi yang terjadi dikalangan mahasiswa lebih tinggi dibandingkan populasi pada umumnya. Hal ini dapat menghambat keberhasilan studi, produktifitas serta konsentrasi mereka (Darmadi, 2010).

Survei terkini di Amerika melaporkan bahwa 15-33\% pasien yang berobat ke dokter merupakan pasien dengan gangguan mental. Dari jumlah tersebut minimal sepertiganya menderita gangguan kecemasan. Di Indonesia dari hasil data penelitian dinas kesehatan menunjukkan bahwasanya gangguan kesehatan jiwa yang sering muncul sebagai gangguan fisik adalah 28,73\% pada dewasa dan 34,39\% pada anak-anak (Romadhon, 2002).

Setiap manusia suatu saat akan mengalami masa tegang dalam jangka pendek saat menghadapi masalah-masalah yang telah dikenal seperti tekanan-tekanan karier, sengketa atau pertengkaran keluarga, tekanan-tekanan materi dan keputusasaan-keputusasaan pribadi, dan kita akan menyangka bahwa inilah depresi, yang bukan merupakan sebuah masalah penting karena akan terselesaikan dengan sendirinya, akan tetapi tidak satupun dari kondisi-kondisi yang cepat berlalu ini merupakan depresi.

Depresi adalah sebuah bentuk penyimpangan perilaku atau sentimen pada diri seseorang yang bisa dikenali dengan bantuan serangkaian indikasi yang terefleksi dalam perilaku-perilaku lisan dan non-lisan, yang muncul berdasarkan kondisi lingkungan atau sebagian dari perubahan-perubahan fisiologis (Fausiah \& Julianti, 2005). Ketiadaan informasi pribadi dan sosial terhadap penyakit depresi telah menyebabkan banyak orang menjadi tersiksa tanpa alasan oleh penyakit ini, dan bahkan sejumlah dari mereka hingga sampai pada batasan melakukan bunuh diri.

Berdasarkan hasil survei yang dilakukan Associated Press-MtvU poll, lebih dari 42\% mahasiswa berusia antara 18-24 tahun di 40 universitas Amerika mengalami depresi karena masalah nilai, percintaan, hutang, dan tugas kuliah. Sedangkan 13\% mahasiswa lainnya 
memiliki ciri rentan terkena depresi. Mahasiswa yang mengalami depresi itu mengaku sulit tidur, putus asa, dan banyak diantaranya belum ditangani dokter atau bantuan profesional lainya. Bahkan 7\% di antara mahasiswa yang mengalami depresi itu, memiliki pikiran lebih baik menyakiti diri sendiri atau mati.

Dr. Thomas Insel, Direktur National Institute for Mental Health, mengatakan mahasiswa seharusnya mengerti depresi dapat menyebabkan "penyakit yang mengancam". Konselingkonseling di kampus menjadi suatu tempat perawatan yang baik untuk penyakit kejiwaan ini. Namun sayang, mahasiswa rupanya malu mengakui jika mereka sedang mengalami depresi karena depresi dianggap sebagai sesuatu yang negatif.

Seperti kasus yang terjadi pada bulan Februari awal tahun 2014 ini, dimana ada seorang mahasiswi Univ Swasta di Jakarta, ditemukan bunuh diri dengan melompat dari lantai 5 sebuah gedung. Kejadian ini diduga karena korban merasa malu dikarenakan belum bayar uang kuliah. Menurut keterangan dari orang tua maupun saudara korban, bahwa mereka tidak mengetahui informasi tentang tekanan yang dirasakan oleh korban. Kondisi ini terjadi tidak ada komunikasi yang jelas dari korban, dia hanya mengirimkan sms yang berisi penyataan sayang kepada ibunya sebelum meninggal.

Perasaan-perasaan negatif seperti kesedihan, kekhawatiran, dan frustrasi merupakan perasaan-perasaan yang umum dirasakan oleh banyak orang. Merupakan suatu hal yang wajar jika anda merasa kecewa setelah mengalami kegagalan, sedih, perpisahan atau kehilangan. Depresi merupakan perasaan yang dialami oleh setiap orang pada satu masa dalam kehidupan mereka. perasaan-perasaan tersebut justru dapat digunakan untuk keuntungan kita karena perasaan-perasaan tersebut menunjukkan kelemahan kita. Pengalaman yang muncul dari kondisi negatif dalam hidup kita tersebut memberikan kita keberanian dan kemauan untuk mengubah hidup kita serta kekuatan untuk menangani depresi dan situasi negatif lainnya di masa yang akan datang.

Berdasarkan penelitian, semakin meningkat usia anak maka angka kejadian depresinya makin meningkat. Dari data penelitian di Amerika, didapatkan gejala depresi pada remaja umur 11-13 tahun (remaja awal) lebih ringan secara bermakna dibandingkan dengan gejala depresi pada umur 14 tahun (remaja menengah) dan umur 17-18 tahun (remaja akhir). Remaja 
awal dengan gejala depresi lebih sering mengeluh dirinya kurang menarik dan ingin berat badannya turun dari pada remaja akhir. Remaja dengan sosio-ekonomi lebih rendah, lebih berat gejala depresinya daripada remaja dengan sosio ekonomi yang lebih tinggi (Tri Utami Dewi \& Pantja Juni Wulandari, 2012).

Dalam kaitannya dengan depresi, banyak penelitian yang telah dilakukan dan tidak kurang dari 80 makalah yang telah dipublikasikan yang berkesimpulan bahwa komitmen agama bermanfaat bagi upaya pencegahan depresi dan dapat bertindak sebaga kekuatan pelindung dan penyangga seseorang dari resiko menderita depresi (Hawari, 2005).

Fenomena yang banyak dilihat dari permasalahan mahasiswa terhadap tekanantekanan kehidupan yang mereka hadapi, memunculkan beberapa penelitian tentang depresi terhadap mahasiswa, diantaranya penelitian yang dilakukan oleh Dina Widhi Asih dari UNIKA Semarang, yang meneliti tentang Hubungan Problem-Focused Coping dengan depresi pada mahasiswa tingkat akhir. Dalam penelitian ini dia menyampaikan bahwa tekanan yang dialami mahasiswa kaitannya terhadap tugas-tugas dan tuntutan tanggung jawab dalam belajar, ditambah lagi persoalan-persoalan sosial dengan teman dan lingkungan kampus, terkadang membuat mahasiswa mengalami perubahan emosi yang berakibat dapat kondisi depresi. Sehingga proses penyelesaian masalah dengan strategi fokus pada masalah satu demi satu, merupakan bentuk coping yang efektif untuk membantu mahasiswa dalam menyelesaikan masalah yang mereka temui (Asih, 2006).

Pengertian yang disampaikan oleh Goleman, bahwa kecerdasan emosi yang baik dapat mengurangi agresi, khususnya pada remaja. Oleh sebab itu apabila emosi berhasil dikelola maka individu akan mampu menghibur diri ketika ditimpa kesedihan, dapat melepas kecemasan, kemurungan atau ketersinggungan dan bangkit kembali dengan cepat dari itu semua. Sebaliknya, individu yang kemampuannya dalam mengelola emosi kurang baik, maka akan terus menerus bertarung melawan perasaan murung atau melarikan diri pada hal-hal yang merugikan diri sendiri (Goleman, 2007).

Berdasarkan uraian latarbelakang sebelumnya, dapat ditarik benang merah, bahwa terdapat keterkaitan antara kecerdasan emosi dengan kemampuan pengelolaan emosi sebagai 
satu dampak utama penyebab kondisi depresi. Oleh karena itu peneliti tertarik untuk meneliti bagaimana “Kecerdasan Emosi dan Depresi Pada Mahasiswa yang Sudah Menikah".

\section{Metode}

Rancangan dalam penelitian ini menggunakan pendekatan kuantitatif, yaitu penelitian yang datanya merupakan pendekatan angka. Penelitian ini bertujuan untuk mengetahui hubungan variable $\mathrm{X}$ dan $\mathrm{Y}$, oleh karenanya jenis penelitian ini adalah korelasional.Responden yang menjadi populasi dalam penelitian ini adalah seluruh mahasiswa IAIN Antasari Banjarmasin,di strata 1 yang berstatus sudah berkeluarga (menikah) dan masih aktif dalam perkuliahan. Secara umum jumlah mahasiswa IAIN Antasari mencapai 1500 mahasiswa, namun tidak semua mahasiswa tersebut yang sudah menikah. Untuk jumlah pasti berapa mahasiswa yang sudah berkeluarga, sehingga untuk pengambilan sampel akan dilakukan dengan teknik Purposif Sampling. Teknik sampling Purposif ini mensyaratkan sampel yang akan menjadi subjek penelitian adalah mahasiswa yang sudah menikah dan masih aktif dalam proses perkuliahan di kampus.

Metode yang akan digunakan dalam penelitian ini adalah analisis statistik, sehingga dapat diambil kesimpulan. Statistik berarti cara-cara ilmiah yang dipersiapkan untuk mengumpulkan, menyusun, menyajikan dan menganalisa data penelitian yang berbentuk angka-angka dan diharapkan dapat menyediakan dasar-dasar yang dapat dipertanggung jawabkan untuk menarik kesimpulan-kesimpulan yang besar dan untuk mengambil keputusan-keputusan yang baik.

Teknik analisis data pada penelitian ini menggunakan analisa regresi umum, yaitu suatu metode untuk meramalkan pengaruh dan besarnya pengaruh variable bebas terhadap variable terikat dengan menggunakan prinsip - prinsip regresi dan korelasi. Dengan analisa regresi juga memungkinkan mengetahui sumbangan relative dan efektif variabel bebas (Hadi, 1994). Untuk menentukan tingkat hubungan peneliti melakukan pengkategorian menjadi tiga tingkatan, yaitu tinggi, sedang, dan rendah. Klasifikasi kategori ini menggunakan harga Mean dan Standar Deviasi (Azwar, 2003) 


\section{Hasil}

Instrument penelitian yang digunakan sudah merupakan instrument baku yang telah diuji validitasnya, sehingga dalam penelitian ini peneliti tidak lagi melakukan uji validitas. Oleh karenanya pelaksanaan penelitian ini hanya melakukan uji reliabilitas, untuk mengetahui tingkat kesesuaian instrument atas situasi dan kondisi lapangan.

Reliabilitas menunjukkan pada suatu pengertian bahwa suatu instrumen cukup dapat dipercaya untuk digunakan sebagai alat pengumpul data karena instrumen tersebut sudah baik. Dimana instrumen tersebut tidak bersifat tendesius sehingga bisa mengarahkan responden untuk memilih jawaban tertentu (Arikunto, 2005). Dari hasil uji reliabilitas dengan menggunakan program SPSS 19 for windows. Untuk skala Kecerdasan Emosi diperoleh hasil 0,822 dan untuk skala BDI diperoleh hasil 0,756.

Deskripsi data merupakan gambaran atau penjabaran dari data yang diteliti setelah dilakukan penelitian untuk mengungkapkan tingkat Kecerdasan Emosional dan tingkat Depresi pada mahasiswa yang sudah menikah.

\section{Analisis Data Kecerdasan Emosi}

Berdasarkan dari nilai Mean pada skala kecerdasan emosi adalah 163,37 dan standar deviasi adalah 13,17. Dari hasil tersebut dapat ditentukan jumlah subjek yang berada di kategori tingkat tinggi ada 6 orang $(17,14 \%)$, kategori tingkat sedang ada 24 orang $(68,57 \%)$, dan dalam kategori tingkat rendah 5 orang (14,28\%). Hal ini menunjukkan bahwa sebagian besar mahasiswa yang telah bekeluarga mempunyai kecerdasan emosional yang sedang.

Analisis Data Depresi (BDI)

Berdasarkan dari nilai Mean pada skala kecerdasan emosi adalah 20,3 dan standar deviasi adalah 6,7. Dari hasil tersebut dapat ditentukan jumlah subjek yang berada di kategori tingkat tinggi ada 4 orang (11,42\%), kategori tingkat sedang ada 25 orang $(71,42 \%)$, dan dalam kategori tingkat rendah 6 orang $(17,14 \%)$. Hal ini menunjukkan bahwa sebagian besar mahasiswa yang telah bekeluarga mempunyai kecerdasan emosional yang sedang.

\section{Hasil Uji Hipotesis}

Hasil uji hipotesis dilakukan dengan menggunakan teknik korelasi product moment dari Karl Pearson, karena terdiri dari dua variabel dengan menggunakan bantuan program SPSS 
19 for windows, untuk mengetahui apakah ada hubungan negative antara kecerdasan emosional dengan depresi pada mahasiswa yang telah menikah. Adapun kesimpulan tersebut diambil berdasarkan buku Aritonang, yaitu : Apabila taraf signifikansi $<0,05$ dan Apabila nilai rxy $>\mathrm{r}$ tabel (Aritonang, 2005). Didapatkan hasil bahwa ada hubungan negatif yang signifikan $(r \mathrm{xy}=-$ $0,411 ; \operatorname{sig}=0,014 \leq 0,05)$ antara Kecerdasan Emosi dengan Depresi. Dengan hasil $r$ tabel =0,334 dan $\mathrm{r} x y(\mathrm{r}$ hit $)=0,411$. Dikatakan signifikan apabila $\mathrm{r} x y=0,411>\mathrm{r}$ tabel $=0,334$.

Dengan demikian hipotesis yang menyatakan bahwa ada hubungan negatif antara kecerdasan emosi terhadap depresi pada mahasiswa yang telah menikah diterima. Artinya apabila semakin tinggi tingkat kecerdasan emosi mahasiswa maka semakin rendah tingkat depresi, begitu pula sebaliknya apabila kecerdasan emosional mahasiswa rendah maka semakin tinggi tingkat depresi. Besar hubungan kecerdasan emosi terhadap depresi sebesar $16,9 \%$, ini berarti variabel lain yang mempengaruhi depresi sebesar 83,1\%.

\section{Pembahasan}

Mahasiswa yang merupakan tahap perkembangan antara remaja dengan dewasa awal. Dimana dalam fase ini banyak problematika yang mereka hadapi, sebagai masa transisi kondisi stressor cukup banyak mempengaruhi bagaimana mahasiswa mengendalikan emosionalnya agar dapat tampil dengan baik, dan tidak membuat mereka terperangkap dalam kondisi depresi. Berdasarkan hasil penelitian ini diperoleh data tentang kecerdasan emosional pada mahasiswa yang telah menikah dominan berada pada kategori sedang, sebanyak 68,57\% yaitu 24 subjek, sedangkan pada kategori tinggi 17,14\% yaitu 6 subjek, dan yang berada dikategori rendah 14,28\% yaitu 5 subjek. Secara umum dapat diketahui bahwa tingkat kecerdasan emosional mahasiswa yang menikah berada pada tingkat sedang, dan selebihnya ada sebagian kecil yang berada pada level tinggi dan sebagain kecil lagi rendah.

Kecerdasan emosi merupakan modal dasar bagi setiap manusia dalam menghadapi setiap tekanan-tekanan dalam kehidupan. Banyak orang terjebak dalam kondisi stress bahkan depresi saat kurang memiliki keterampilan yang baik dalam menghadapi masalah-masalah kehidupan. Kecerdasan emosi merupakan kemampuan seseorang dalam mengelola kondisi emosional untuk mampu bersikap dan bereaksi sesuai dengan kondisi yang dihadapi. Hal ini 
seperti yang di sampaikan Goleman, Kecerdasan emosional adalah kemampuan lebih yang dimiliki seseorang dalam memotivasi diri, ketahanan dalam menghadapi kegagalan, mengendalikan emosi, serta mengatur keadaan keadaan jiwa (Goleman, 2007).

Pada dasarnya setiap manusia pasti mendapatkan ujian dan cobaan yang berupa masalah-masalah ataupun konflik-konflik dari Tuhan, yang kondisi tersebut membutuhkan kemampuan kecerdasan emosional yang baik untuk dapat melalui dengan lancar. Sebagaimana firman Allah, dalam QS. Al-Baqarah ayat 155 berbunyi:

"dan sungguh akan Kami berikan cobaan kepadamu, dengan sedikit ketakutan, kelaparan, kekurangan harta, jiwa dan buah-buahan. dan berikanlah berita gembira kepada orang-orang yang sabar"

Ayat tersebut memberitahukan bahwa setiap manusia yang hidup akan mendapat cobaan, oleh karena itu bagi orang-orang yang mampu bersabar merupakan kabar gembira. Orang yang memiliki kecerdasan emosi yang baik, maka juga mampu mengelola emosinya untuk tetap stabil, dan terus memahami kondisi masalah yang dihadapi secara sadar dan optimis.

Berdasarkan hasil penelitian ini diperoleh data tentang depresi pada mahasiswa yang telah menikah dominan berada pada kategori sedang, sebanyak 71,42\% yaitu 25 subjek, sedangkan pada kategori tinggi 11,42\% yaitu 4 subjek, dan yang berada dikategori rendah 17,14\% yaitu 6 subjek. Secara umum dapat diketahui bahwa tingkat depresi mahasiswa yang menikah berada pada tingkat sedang, dan selebihnya ada sebagian kecil yang berada pada level tinggi dan sebagain kecil lagi rendah.

Depresi merupakan salah satu gangguan mood yang berawal dari kondisi stress yang tidak ditangani secara baik. Seseorang dapat mengalami depresi yang di awali dengan perasaan sedih yang mendalam. Di kalangan mahasiswa dewasa ini banyak hal yang dapat menyebabkan depresi, selain kondisi emosional yang cenderung masih labil, tuntutan tugas kuliah yang tinggi, standart nilai yang tinggi, hasil belajar yang kurang memuaskan, serta masalah-masalah yang berhubungan dengan relasi lingkungan pergaulan.

Masalah depresi biasanya berawal dari diri sendiri yang kemudian mempengaruhi lingkungan dan aktifitas rutin sehari-hari. Lingkungan tentu memberikan reaksi terhadap 
perilaku orang depresi yang pada umumnya negative, seperti mudah marah, mudah tersinggung, sensitive, suka menyendiri, mudah lelah, dan mudah sakit. Masalah sosial yang terjadi biasanya merupakan masalah interaksi dengan teman, pasangan, dan dosen. Masalah tidak selalu dalam bentuk konflik, namun seperti perasaan minder, malu, cemas, tidak nyaman saat bersama kelompok, kaku dalam berkomunikasi secara normal. Merasa tidak mampu untuk bersikap terbuka dan secara aktif menjalin hubungan dengan lingkungan sekalipun ada kesempatan.

Sesungguhnya Allah telah menjanjikan derajat yang tinggi bagi setiap manusia yang mampu mengatasi perasaannya. Sebagaimana firman Allah dalam QS. Ali-Imran: 139, yaitu:

"Janganlah kamu bersikap lemah, dan janganlah (pula) kamu bersedih hati, Padahal kamulah orangorang yang paling Tinggi (derajatnya), jika kamu orang-orang yang beriman".

Ayat tersebut, Allah memberikan penjelasan, bahwasanya jika kita merupakan manusia yang beriman, maka janganlah bersikap lemah dan bersedih hati, karena orang beriman merupakan orang yang berada pada derajat yang paling tinggi.

Hasil analisis data dengan teknik korelasi product moment dari Pearson menunjukkan bahwa ada hubungan negatif yang signifikan $(r X Y=0,411 ;$ sig $=0,014<0,05)$ antara kecerdasanemositerhadap depresi. Dengan hasil $\mathrm{r}$ tabel $=0,334$ dan $\mathrm{r}$ xy ( $\mathrm{r}$ hit) $=-0,411$. Dikatakan signifikan apabila $\mathrm{r}$ xy $=0,411>\mathrm{r}$ tabel $=0,334$. Besar pengaruh kecerdasanemositerhadap depresi $\left(r^{2} \times 100\right)$ sama dengan $16,9 \%$, ini berarti variabel lain yang mempengaruhi depresisebesar 83,1\%. Karena keterbatasan waktu dan biaya maka peneliti mengambil satu variabel saja untuk diteliti yaitu kecerdasan emosi sebagai variabel yang mempengaruhi depresi.

Hasil penelitian di atas mengungkapkan bahwa kemampuan kecerdasan emosi dapat mempengaruhi kecenderungan depresi pada seseorang. Khususnya pada usia-usia rentan stress yaitu di usia remaja akhir dan dewasa awal. Dimana depresi yang nyata dapat dilihat pada anak usia lebih 10 tahun terutama pada usia remaja, di mana superego, kemampuan verbal, kognitif dan kemampuan menyatakan perasaannya sudah berkembang lebih matang sehingga gejala depresi pada usia ini mirip dengan gejala depresi pada orang dewasa. Penggunaan proses berpikir secara realistik makin berkembang, penggunaan fantasi sebagai 
alat pelarian makin hilang, sudah tidak menggunakan mekanisme pembelaan yang primitive dan makin berkembangnya suara hati nurani (superego) yang akan memperhebat perasaan bersalah dan rendah diri (Prasetyono, 2007).

Sebagaimana yang disampaikan oleh Goleman bahwa para mahasiswa yang berprestasi tinggi ternyata banyak yang tidak mempunyai keberhasilan yang lebih tinggi dari pada mahasiswa yang berprestasi biasa-biasa saja.Sebaliknya mahasiswa yang mempunyai prestasi biasa-biasa saja justru mempunyai tingkat keberhasilan yang tinggi dibandingkan dengan yang berprestasi akademik tinggi di kemudian hari. Hal itu dikarenakan mahasiswa yang berprestasi tinggi kebanyakan memiliki emosi yang terlampau ditekan, terlampau ekstrim dan bila berlangsung secara terus menerusakan menjadi sumber penyakit (Goleman, 2007).

Selain itu, emosi dengan intensitas yang tinggi akan melampaui titik wajar dan beralih menjadi kecemasan kronis, amarah yang tidak terkendali dan depresi. Diketahui bahwa kecerdasan emosi yang tinggi akan berpengaruh terhadap keberhasilan seseorang, karena seseorang yang mempunyai kecerdasan emosi yang tinggi tidak akan mudah masuk pada kondisi depresi. Hal ini sebagaimana yang diungkapkan oleh Purwanto dan Lestari bahwa kecerdasan emosi mencakup kemampuan untuk memotivasi diri dan bertahan terhadap frustasi, kemampuan untuk mengontrol impuls dan menunda pemuasannya, kemampuan untuk mengatur perasaan (mood) dan mencegah keadaan yang berbahaya yang mempengaruhi kemampuan berpikir, serta kemampuan untuk berempati dan menolong orang lain (Prasetyono, 2007).

\section{Kesimpulan}

Berdasarkan hasil dan pembahasan yang dipaparkan dalam penelitian ini, maka dapat di simpulkan bahwa dari hasil uji hipotesis diperoleh hasil bahwa antara kecerdasan emosi dengan depresi pada mahasiswa yang telah menikah mempunyai hubungan negatif yang signifikan $(r \mathrm{xy}=-0,411 ; \operatorname{sig}=0,014<0,05)$. Hal ini sesuai dengan data yang telah diperoleh dari program SPSS 19 for windows, menyatakan bahwa r tabel 0,334 dan r xy (r hit) -0,411, dikatakan signifikan apabila $\mathrm{r} x y=0,411>\mathrm{r}$ tabel $=0,334$. Dengan kata lain semakin tinggi kecerdasan emosi mahasiswa yang telah menikah maka semakin rendah kemungkinan mengalami depresi. Pada sampel yang diteliti terdapat 6 orang atau 17,14\% yang berada di kategori tinggi, 24 orang 
atau $68,57 \%$ yang berada di kategori sedang, dan 5 orang atau 14,28\% yang berada di kategori rendah. Oleh karena itu secara umum kecerdasan emosional mahasiswa yang telah menikah di IAIN Antasari tergolong sedang, hal ini dapat dilihat dari prosentasi 68,57\% yang merupakan jumlah terbanyak. Ini menggambarkan 24 sampel dari 35 sampel yang ada. Oleh karena itu dapat di artikan bahwa tingkat kecerdasan emosi pada diri mahasiswa yang sudah menikah berada pada tataran baik. Aspek depresi di bagi menjadi tiga kategori, yaitu tinggi, sedang dan rendah. Pada sampel yang diteliti terdapat 4 orang ataı $l, 42 \%$ yang berada di kategori tinggi, 25 orang atau 71,42\% yang berada di kategori sedang, dan 6 orang atau 17,14\% yang berada di ketegori rendah. Oleh karena itu secara umum depresi mahasiswa yang telah menikah di IAIN Antasari tergolong sedang, hal ini dapat dilihat dari prosentasi 71,42\% yang merupakan jumlah terbanyak. Ini menggambarkan 25 sampel dari 35 sampel yang ada. Oleh karena itu dapat di artikan bahwa tingkat depresi pada diri mahasiswa yang sudah menikah berada dalam tataran cukup baik.

Saran

Penelitian selanjutnya agar memperhatikan jumlah subjek dan juga pendekatan yang digunakan untuk memperdalam hasil temuan penelitian dari berbagai persfektif.

\section{Referensi}

Arikunto, S. (2005). Prosedur Penelitian. Jakarta: Rineka Cipta.

Aritonang, L. R. (2005). Kepuasan Pelanggan Pengukuran dan Penganalisaan dengan SPSS. Jakarta: Gramedia Pustaka Utama.

Asih, D. W. (2006). Hubungan antara Problem Focused Coping dengan Depresi pada Mahasiswa Tingkat Akhir (Skripsi). Fakultas Psikologi UNIKA, Semarang.

Azwar, S. (2003). Tes Prestasi. Yogyakarta: Pustaka Pelajar.

Darmadi, A. (2010). Prevelensi Depresi dan Faktor yang mempengaruhi pada Mahasiswa Fakultas Kedokteran Universitas Atma Jaya (Skripsi). Fakultas Kedokteran Universitas Atma Jaya, Jakarta.

Fausiah, F., \& Julianti, W. (2005). Psikologi Abnormal Klinis Dewasa. Jakarta: UI Press.

Goleman, D. (2007). Emotional Intelligence. Jakarta: Gramedia Pustaka Utama.

Hadi, S. (1994). Metodologi Reasearch Jilid II. Yogyakarta: UGM Press.

Hawari, D. (2005). Dimensi Religi dalam Praktek Psikiatri dan Psikologi. Jakarta: Balai Penerbit FK UI.

Prasetyono, D. S. (2007). Metode Mengatasi Cemas \& Depresi. Yogyakarta: Oryza. 
Romadhon, Y. . (2002). Gambaran Klinik Psikofarmaka Pada Penderita Gangguan Kecemasan. Jakarta: Cermin Dunia Kedokteran.

Tri Utami Dewi, T., \& Pantja Juni Wulandari, A. (2012). Hubungan Antara Kecerdasan Emosional dan Agresi Pada Remaja di Jakarta (Skripsi). Binus, Jakarta. 